
\title{
$\begin{array}{ll}\text { Research Square } & \begin{array}{l}\text { Preprints are preliminary reports that have not undergone peer review. } \\ \text { They should not be considered conclusive, used to inform clinical practice, } \\ \text { or referenced by the media as validated information. }\end{array}\end{array}$
}

\section{Impact of traditional bonesetters on contemporary fracture care in Low and Middle Income Countries (LMICs): a systematic review}

Ndubuisi Onyemaechi ( $\nabla$ ndubuisi.onyemaechi@unn.edu.ng)

University of Nigeria Faculty of Medical Sciences https://orcid.org/0000-0002-4505-3398

William N.A. Menson

Global Health Initiative, School of Community Health Sciences, University of Nevada, Las Vegas USA

\section{Xan Goodman}

Library Liaison Program, University of Nevada, Las Vegas USA

\section{Samantha Slinkard}

Global Health Initiative, School of Community Health Sciences, University of Nevada Las Vegas USA

\section{Obinna E Onwujekwe}

Department of Pharmacology and Therapeutics, College of Medicine, University of Nigeria Enugu Campus, Enugu Nigeria

\section{Ugochukwu N Enweani}

Medical Director, City Clinics Enugu Nigeria

\section{Okechukwu E Nwankwo}

Department of Surgery, College of Medicine, University of Nigeria Ituku-Ozalla Enugu, Nigeria

\section{Benedict C Nwomeh}

College of Medicine, Ohio State University Columbus Ohio USA

\section{Fiemu E Nwariaku}

University of Texas Southwestern Medical Center at Dallas

\section{Echezona E Ezeanolue}

Department of Paediatrics, Moorehouse School of Medicine, Atlanta Georgia USA; Institute of Maternal and Child Health, College of Medicine, University of Nigeria Ituku-Ozalla, Enugu Nigeria

\section{Research article}

Keywords: Systematic review, bonesetters, fracture healing, Low and Middle Income countries

Posted Date: October 5th, 2019

DOI: https://doi.org/10.21203/rs.2.15579/v1

License: @) (1) This work is licensed under a Creative Commons Attribution 4.0 International License. Read Full License 


\section{Abstract}

Background: The review aimed at systematically examining the evidence in articles that assess the clinical effects and impact of traditional bonesetters on contemporary fracture care in Low and Middle Income Countries (LMICs).

Methods: A systematic review was conducted. Articles were identified by database searching ((PubMed, Embase, ScienceDirect, SCOPUS, and Web of Science). Searching, selecting and reporting were conducted according to the PRISMA (Preferred Reporting Items for Systematic reviews and Meta-Analyses) Statement. The key words that were used in search for literature were: "Bonesetter", "fracture healer" and "traditional bone setting". Publications included for review were original articles, set in an LMIC and directly talked about the role and/or impact of traditional bonesetters in providing fracture care. Papers that focused on Low and Middle Income (LMIC) settings were reviewed.

Results: A total of 176 papers were screened for eligibility and 15 studies were finally included. Nine were prospective studies, while 6 were retrospective studies. Most of the studies focused on clinical impacts of bone setter intervention. The evidence from the publications show that the main clinical effects of traditional bonesetters had been deleterious, but they had the potential to contribute positively when trained.

Conclusion: Few well designed studies are available that assessed the impact of traditional bonesetters. Reported cases and reviews indicate their impact to be deleterious. However, the potential exist that when trained, these deleterious impact can be reduced through training for traditional bonesetters who contribute to fracture care in many LMICs.

\section{Introduction}

In most Low and Middle Income countries (LMICs), traditional bonesetters (TBS) still play an integral role in trauma care [1]. The practice of traditional bone setting dates back to history and it has found root in many developing countries in Africa, South America and the Indian subcontinent where TBS still play a role in providing services [2]. In many developing countries, traditional care of injuries and diseases has remained popular despite the existence of modern health care services and advancement in various spheres of life [2,3]. Bone setting skills are usually passed down the family line without any documentation. TBS receive no formal training in modern orthopaedic care and their practice is kept a family secret and as part of an ancestral heritage [4].

Despite the presence and availability of modern orthopaedic services (MOS), TBS enjoy high patronage and wide acceptance across different social and educational strata as well as religions [5].The high patronage of TBS is rooted in cultural belief and has no correlation with educational status, income or occupation [3].Cultural beliefs, expectations of quicker healing, cheaper services and fear of amputation have been noted as reasons for TBS patronage in some studies $[6,7,8]$. The low coverage of health insurance and high out-of-pocket costs of healthcare in most developing countries also contribute to the poor utilization of MOS [9].

In Nigeria, TBS provide about $70 \%-90 \%$ of primary fracture care in certain areas [10] and this method of fracture care cannot be overlooked, as it has a huge impact on health outcomes. Many patients with fractures would preferentially present directly to the TBS or after initial resuscitation in a hospital.

The bone setting techniques adopted by the TBS lack a sound scientific basis which may lead to limb and life-threatening complications [11]. Various complications and failure rates of TBS treatment have been reported. Oginni [12] and OlaOlorun et al. [13] both in southwest Nigeria, have reported complication rates of $66.7 \%$ and $83 \%$ respectively, while Faheem et al. [14] in India reported $43 \%$. Onuminya [9]also observed that $50-60 \%$ of limb gangrene in Nigeria were due to complications of TBS practice.

Some complications from TBS interventions include: non-union, mal-union, chronic osteomyelitis, limb gangrene, compartment syndrome and joint stiffness $[9,11,15,16]$. These complications constitute management challenges to orthopaedic surgeons in developing countries as they increase the case load and lead to orthopaedic surgeons treating complications of fractures $[4,12]$. 
This systematic review aims to provide a concise overview of current knowledge base of the impact of TBS on fracture care, identify gaps in knowledge and potential areas for future research to assess impact of well-designed interventions on outcome for patients who patronize TBS.

\section{Methods}

This systematic review was conducted based on the PRISMA (Preferred Reporting Items for Systematic reviews and MetaAnalyses) framework in order to assure quality of the search process and adequate reporting within this paper [17].

\section{Search Strategy}

Articles were identified by database searching (PubMed, Embase, ScienceDirect, SCOPUS, and Web of Science). A secondary search was conducted using three WHO indexes: Hinari Access to Research for Health program, Institutional Repository for Information Sharing (IRIS) and the Global Index Medicus (GIM). The time period used was from 1900 to May 2017. Titles, abstracts, key words and full texts were searched with the following search term: ("bonesetter" OR "fracture healer" OR "Traditional bone setting"). The search strategy used for the PubMed search was 'bonesetter' OR 'traditional bone setting' OR 'fracture healer' AND 'Fractures' OR 'injuries' OR 'musculoskeletal injuries' AND 'fracture care' Or 'treatment'. The search strategy was adapted for each database as necessary. Furthermore, a manual search was conducted to identify relevant articles in the reference lists of the identified articles which meet the inclusion criteria.

\section{Inclusion Criteria}

Articles which were included in this systematic review had to meet the following criteria: 1) set in an LMIC; 2) published in English; 3) articles published in peer reviewed journals between 1900 and 2018; 4) directly mentioned the impact of traditional bonesetters' treatment of fractures; 5) articles that evaluated the clinical complications of fractures resulting from traditional bonesetters' treatment.

\section{Exclusion Criteria}

Articles were excluded if the paper: i) was a literature review, letter, comment or conference abstract ii) described a theoretical concept but did not directly address the role or impact of traditional bonesetters iii) had no abstract. Case reports, case studies and qualitative studies were excluded. Study eligibility for inclusion was assessed in duplicate by two authors, and in cases of discrepancy, a third author was consulted to reach a consensus.

\section{Data Extraction and Synthesis}

Titles and abstracts were initially screened for their fulfilment of inclusion criteria. Subsequently, the remaining potentially eligible articles were appraised in detail by reading the full-text papers.

All the retained papers were reviewed independently by two sets of two authors who examined the full texts using a data extraction pro-forma developed and pre-tested by the review team. The data extraction pro-forma was used to extract the following: the study setting, the study design, the study objectives, study population, sampling techniques, the treatment received, outcome of the TBS treatment, study limitations and conflicts of interest. Cases of non-concordance were resolved by another author. If there were any discrepancies between the two sets of authors, a fifth author adjudicated.

The outcome measures assessed included clinical impacts and how the work of TBS has affected the outcomes of fracture treatment. Relevant information was extracted into a narrative summary table designed for this review. The table contained fields for author information, country of study, study setting, study population and design, impact of TBS treatment and 
summary of relevant results. The summary table was developed by two authors and validated by the review team. Impact was defined as 'the effect of bone- setters on how fractures are treated and the clinical outcomes as a result of intervention by bonesetters'.

\section{Quality Assessment}

We assessed the quality of the included studies using the National Heart, Lung, and Blood Institute (NHLBI) Quality Assessment Tool for Observational Cohort and Cross-Sectional Studies, which is widely used and recommended by Cochrane for quality assessment of observational and cross-sectional studies [18]. The tool assessed the internal validity and risk of bias of the included studies using a checklist of 14 questions with responses, yes, no or others (cannot determine, CD; not applicable, NA; and not reported, NR). Two authors applied the tool and independently evaluated the items of the tool as "yes, " "no, " "not applicable, " "cannot determine, " or "not reported." This was used to guide the overall rating for the quality of each study as "good," "fair," or "poor." Where there was a disagreement, consensus was reached through discussion or by consulting a third author.

\section{Results}

\section{Study selection}

The database search yielded 192 results (Embase-41; PubMed- 28; Science Direct- 5; Cochrane-1; SCOPUS- 91; Web of Science- 26). Fifty four articles were identified through other sources. After the exclusion of duplicates, there were 176 articles eligible for further screening. Title and abstract screening according to the selection criteria led to the exclusion of 143 articles, leaving 33 articles for full-text assessment. After a careful review of these 33 articles, 15 were selected for inclusion in the current systematic review. The process of study selection is depicted in a flow diagram (Figure 1).

\section{Study characteristics}

Table 1 provides an overview of the main characteristics of the 15 studies included in our systematic review. Three of the articles were from Nigeria and about the impacts of traditional bone setting in Nigeria. Two articles each were from India, Sudan and Pakistan. One article each was from Ghana, Turkey, China, Indonesia, Ethiopia and Bangladesh. Altogether, seven studies (46.7\%) were from the African continent while, eight studies (53.3\%) were from Asia. The studies were published between 1986 and 2018. Ten out of the 15 studies were published between 2010 and 2018. All the studies were original articles from hospital-based, observational studies that investigated the outcomes of treatment of fractures by TBS. Nine of the studies were prospective while six were retrospective studies about patients who had previously been attended to by a traditional bonesetter after sustaining a musculoskeletal injury. None of the studies was a randomized controlled study or a systematic review. Further analysis of the studies showed that 1389 participants with 1470 complications of fracture treatment were studied. The age of the participants ranged from 6 weeks to 86 years with a mean age of 29.4 years. About $68.1 \%$ of the participants were males while $31.9 \%$ were females. The duration of studies ranges from 6 months to 5 years with a mean duration of 2.2 years.

\section{Quality of included studies}

We assessed the methodological quality of the studies according to the NHLBI assessment tool. Most of the studies were of intermediate quality (53.3\%), $26.7 \%$ were of high quality and $20 \%$ of poor quality (table 2 ). Almost all the included studies had clearly stated research questions and objectives with clearly specified and defined study population. The most frequently unreported criteria were the loss to follow-up after baseline of $20 \%$ or less and the participation of eligible persons of at least $50 \%$. In most of the included studies, the exposure and outcome measures were clearly defined, valid, reliable and implemented consistently across all the study participants. Other commons strengths included the clearly defined inclusion and exclusion 
criteria for being included in the studies which were pre-specified and applied uniformly to all participants. Blinding of the outcome assessors to the exposure status of the participants was considered not to be applicable in the included studies. Only two of the studies reported that key potential confounding variables were measured and adjusted statistically for their impact on the relationship between exposures and outcomes.

\section{Outcomes of selected articles}

The outcome measures assessed were the presence of any musculoskeletal complications resulting from the treatment of a fracture by a traditional bonesetter. A range of indicators were employed for evaluation of outcomes. The most common complications that resulted from TBS treatment of fractures were: malunion, non-union, limb gangrene, compartment syndrome, joint stiffness, limb shortening and chronic osteomyelitis. Limb gangrene was a common complication amongst children $[4,22,25]$. Two studies examined the methods of treatment by TBS that resulted in complications. The local splints used by TBS in immobilizing limb fractures was noted to be a major cause of gangrene in children [15, 25]. One of the studies analyzed the cost effectiveness of TBS treatment. It was noted that the cost of treatment of the TBS ranged from USD 18-380, whereas the treatment of certain fractures at an orthopaedic hospital in Nigeria ranged from USD 34-98 [19]. The impact of TBS on treatment outcomes of fractures was generally found to be negative, reversing gains made by orthodox fracture care and leading to deleterious complications in many LMICs (Table 1).

\section{Discussion}

A total of 15 studies were fully reviewed in order to examine the impact of traditional bonesetters on fracture care in LMICs. Given the widespread influence and popularity of traditional bonesetters in many LMICs, this is surprisingly a low number. This revealed to us that the subject of bonesetters is an understudied one. Most of the articles included were set in Asia and SubSaharan Africa. This may be explained by the existence of TBS and their wide-spread patronage in these regions. Some of the papers which appeared with our search gave a historical account and examined factors that led to many people choosing TBS over orthodox medical practitioners, with few examining their impact on fracture care. Most of the articles included in this systematic review were set in English-speaking countries. This finding could be due to the inclusion criterion that required all articles to be in English or a greater familiarity with bone setters in English speaking countries than others.

It is worth observing that all the impacts of TBS interventions identified in the studies reviewed were of a clinical nature, with the most common impacts being Malunion, nonunion, limb gangrene, amputations, and compartment syndrome. These may be attributable to the non-scientific nature of their treatment methods which was highlighted by two studies $[15,25]$. The studies reported that the local splints applied by TBS in immobilizing limb fractures were applied too tightly resulting in compartment syndrome, Volkmann's ischemic contracture and gangrene. The health and socioeconomic impact of these complications are enormous because young adults in the reproductive age are predominantly involved. These complications also pose a management challenge to orthopaedic surgeons in the developing countries resulting in poor outcomes of fracture treatment $[4,11,12]$.

In spite of the generally poorer outcomes associated with traditional bone setters relative to orthodox medical treatment, large numbers of people in LMICs continue to patronize their services. This is due to the absence of orthodox medical services, perceived cheaper services, the perception that they are more competent at treating fractures, discomfort in cast, the fear of surgery, mistrust of doctors among others $[1,9,33,34,35,36]$. Dada et al [19] in their study also analyzed the differential cost of fracture treatment between the TBS and orthopaedic surgeons at an orthopaedic hospital in Nigeria. It was noted that the cost of fracture treatment by the TBS ranged from USD 18-380, while that in the orthodox hospital ranged from USD 34-98. This is contrary to a widely held opinion in many LMICs that TBS treatment of fractures is cheaper than orthodox treatment.

Another important impact of TBS intervention, as identified in several of the articles reviewed was that patients who sought initial help from TBS before visiting the hospital were more likely to have poorer outcomes than those who sought initial care 
from orthodox hospitals $[24,33]$. This is usually as a result of TBS gangrene that may follow treatment by a TBS which might lead to amputation, sepsis, or death in some cases [22].

Many experts have recommended that because of the widespread presence of TBS and the influence and respect they command among a lot of people in LMICs, efforts should be made to retrain them and possibly integrate them into the formal health system $[34,35]$. Interviews with bone setters on this issue have elicited different responses; with some welcoming the idea and others rejecting it because they consider orthodox medical practitioners their competitors [36]. Onuminya [37] demonstrated that the training of a TBS resulted in a considerable decrease in the rate of gangrenous limbs, infection, nonunion and malunion, when the operations of two bone setters were compared- one who had undergone training by orthodox medical practitioners and the other who had not.

\section{Strengths and weaknesses}

To the best of our knowledge, this systematic review is the first on the subject of traditional bonesetters and their impact on fracture outcomes and contemporary treatment of fractures. Taking into account the multifaceted nature of the subject of traditional bonesetters, we chose a search strategy which encompassed databases in biomedical as well as social sciences. The objective of this systematic review was clear-cut with a robust methodology to achieve it. The database search and study selection were performed in a systematic and documented manner, using the PRISMA Statement for conducting systematic reviews. The methodological quality of the included studies was appraised using the NHLBI assessment tool for internal validity and risk of bias.

There are however some limitations to this review. Our search strategy was limited to established scientific databases and grey literature in the WHO databases. This might have led to the exclusion of articles which are not found in these databases. Also, the fact that most of the articles which were eventually included were hospital-based studies may not be representative of the actual impact of TBS treatment of fractures since minor complications and fatalities may not have presented to the hospitals. Thus, all conclusions drawn in the present paper are limited to the 'established' databases and manual searching. It is difficult to tell how this search strategy may have affected the results of our review.

\section{Conclusion}

Our review identifies that currently, TBS provide huge services to individuals with trauma and bone fractures in many LMICs. Most of the reported outcomes have been deleterious. However, there is potential that when TBS are trained, they can contribute positively to fracture care and outcomes. Innovative interventions that can lead to improvement in the reported negative impact for individuals with fractures who patronize TBS should be tested in well-designed studies, and if proven to work should be adopted.

\section{Abbreviations}

LMIC: Low and Middle Income Countries

USA: United States of America

TBS: Traditional Bonesetters

MOS: Modern Orthopaedic Services

PRISMA: Preferred Reporting Items for Systematic reviews and Meta-Analyses

WHO: World Health Organization

\section{Declarations}


Ethics Approval and Consent to Participate: The research and ethics committee of University of Nigeria Teaching Hospital ItukuOzalla gave approval for the study.

Consent to publish: Not applicable

Availability of data and materials: The datasets used and/or analyzed during the current study are available from the corresponding author on reasonable request.

Competing interest: The authors declare no competing interests.

Funding: No financial assistance was received for this study. The study was self-funded by the authors.

Acknowledgement: Not Applicable.

Authors' contributions: EEE and FEN conceived the study. XG and SS designed the protocol for the systematic review. NOO, OEO, OEN and WNAM conducted the literature search. Titles and abstracts were initially screened for their fulfilment of selection criteria. Two of the authors (NOO and SS) conducted the screening procedure independently from each other. Cases of nonconcordance were resolved by another author (WNAM). The corresponding data extraction was done by WNAM and NOO. NOO and WNAM drafted the manuscript. BCN, UNE, XG, EEE and FEN revised the manuscript. All the authors approved the final version of the manuscript and agree to be accountable for all aspects of the work.

\section{References}

1. Udosen AM, Otei OO, Onuba O. Role of traditional bonesSetters in Africa: Experience in Calabar, Nigeria. Ann Afr Med. 2006;5(4):170-173.

2. Oboirien M, Khalid A. Knowledge And Belief About Traditional Bone Setters' Practices In Sokoto, North-West Nigeria. Internet J Orthop Surg. 2013;21(2).

3. Orjioke C. Does traditional medicine have a place in Primary Health Care? Orient J Med. 1995;7(1):1-3.

4. Onuminya JE, Onabowale BO, Obekpa PO, Ihezue CH. Traditional bone setter's gangrene. Int Orthop. 1999;23(2):111-112.

5. Thanni LO. Factors influencing patronage of traditional bone setters. West Afr J Med. 2000;19(3):220-224.

6. Ogunlusi JD, Oluwadiya KS, Ogunlusi OO, Oginni LM, Oyedeji OA, Ibligaami O. Acquired Boneless Forearm as a Complication of Traditional Bone Setting. Orthopedics. 2008;31(3) 288.

7. Oyebola DD. Yoruba traditional bonesetters: the practice of orthopaedics in a primitive setting in Nigeria. J Trauma. 1980;20(4):312-322.

8. Onyemaechi NOC, Lasebikan OA, Elachi IC, Popoola SO, Oluwadiya K. Patronage of traditional bonesetters in Makurdi north-central Nigeria. Patient Prefer Adherence. 2015:275-279.

9. Onuminya JE. The role of the traditional bonesetter in primary fracture care in Nigeria. South African Med J. 2004;94(8):652-658.

10. Omololu AB, Ogunlade SO, Gopaldasani VK, Omololu AB, Ogunlade SO, Gopaldasani VK. The practice of traditional bonesetting: Training algorithm. Clin Orthop Relat Res. 2008;466(10):2392-2398.

11. Onyemaechi NOC, Onwuasoigwe O, Nwankwo OE, Popoola SO, Schuh A. Complications of Musculoskeletal Injuries Treated by Traditional Bonesetters in a Developing Country. Indian J Appl Res. 2014; 4(3):313-316.

12. Oginni LM. The use of traditional fracture splint for bonesetting. Niger Med Pr. 1992;24:49-51.

13. OlaOlorun DA, Oladiran IO, Adeniran A. Complications of fracture treatment by traditional bonesetters in southwest Nigeria. Fam Pract. 2001;18(6):635-637.

14. Faheem AM, Gulzar S, Bilal F. Complications of fracture treatment by traditional bone setters at hyderabad. J Pak Orthop Assoc. 2009;21(2):58-64. 
15. Chowdhury MA, Khandker HH, Ahsan K, Mostafa D. Complications of Fracture Treatment by Traditional Bone Setters at Dinajpur. Dinajpur Med Col J. 2011;4:15.

16. Hag MIA EL, Hag O EL. Complications in fractures treated by traditional bone setters in Khartoum, Sudan. Khartoum Med J. 2010;3:401.

17. Liberati A, Altman DG, Tetzlaff J, Mulrow C, Gøtzsche PC, John PA. The PRISMA statement for reporting systematic reviews and meta-analyses of studies that evaluate healthcare interventions: explanation and elaboration. BMJ. 2009;339(b2700).

18. www. nhlbi.nih.gov/health-topics/study-quality-assessment/tools

19. Dada A, Giwa SO, Yinusa W, Ugbeye M, Gbadegesin S. Complications of treatment of musculoskeletal injuries by bone setters. West Afr J Med. 2009;28(1):43-47.

20. Callistus KB, Alhassan A, Issahaku M. Fracture complications after treatment by traditional bonesetters in Northern Ghana. Adv Appl Sci Res 2013; 4(6): 207-211.

21. Panigrahi TK, Mishra DN, Padhy N. Fracture management by traditional bonesetters: A hospital based observational study. J Med Sci Clin Res 2017: 5(10): 29177-29182.

22. Nwankwo $\mathrm{OE}$, Katchy AU. Limb gangrene following treatment of limb injury by traditional bone setter (Tbs): a report of 15 consecutive cases. Niger Postgrad Med J. 2005;12(1):57-60.

23. Zehir S, Zehir R, Şahin E, Akgül T, Zehir S, Subaşı M. Bonesetter interventions and consequences. Acta Orthop Traumatol Turc. 2015;49(4):416-420.

24. Huang $\mathrm{CH}$. Treatment of neglected femoral neck fractures in young adults. Clin Orthop Relat Res. 1986 May;(206):117126.

25. Doumi EBA, Osman AM, Hassan EM. Amputations of the upper limb at El Obeid Hospital, Western Sudan: role of traditional bonesetters. Sudan Med J 2009: 45(2): 65-69.

26. Warman PL, Ismiarto YD, Ruhimat U. Complications of fracture treatment by traditional bonesetters in West Java, Indonesia. Athea Med J 2018; 5(1): 47-52.

27. Zulfiqar Z, Bubak SZ, Jahangir A, Ali Z. Frequency of complications among trauma patients treated by traditional bonesetters. JSZMC 2018; 9(3):1456-1458.

28. Dastigir N, Butt KK, Nabeel N. Musculoskeletal injuries by bonesetters. Professional Med J 2012;19(4): 446-448.

29. Kumma WP, Kabalo BY, Witicha EW. Complications of fracture treatment by traditional bonesetters in Wolaita Sodo, Southern Ethiopia. J Bio Agric Healthcare 2013; 3(12): 95-101.

30. Ariës $\mathrm{MJH}$, Joosten $\mathrm{H}$, Wegdam HHJ, van der Geest S. Fracture treatment by bonesetters in central Ghana: patients explain their choices and experiences. Trop Med Int Health. 2007;12(4):564-574.

31. Aderibigbe SA, Agaja SR, Bamidele JO. Determinants of utilization of traditional bone setters in llorin, north central Nigeria. J Prev Med Hyg. 2013;54(1):35-40.

32. Hatipoglu S, Tatar K. The strengths and weaknesses of Turkish bone-setters. In: World Health Forum. Vol 16. S. Hatipoglu, NSGMMA, 06018 Etlik-Ankara, Turkey: Geneva: World Health Organization, 1980-1998.; 1995:203-206.

33. Ajibade A, Akinniyi OT, Okoye CS, A. A, O. T. A, C. S. O. Indications and complications of major limb amputations in Kano, Nigeria. Ghana Med J. 2013;47(4):185-188.

34. Agarwal A, Agarwal R. The practice and tradition of bonesetting. Educ Health (Abingdon). 2010;23(1):225.

35. Bassey R, Aquaisua A, Edagha I, Peters I, Bassey E. The Practice Of Traditional Bone Setting In The South- South Region Of Nigeria. Internet J Altern Med. 2009;8(2):2-7.

36. Odatuwa-Omagbemi DO, Enemudo RE, Enamine SE, Esezobor EE. Traditional bone setting in the Niger Delta region of Nigeria. Niger J Med. 2014;23(2):157-161.

37. Onuminya JE. Performance of a trained traditional bonesetter in primary fracture care. S Afr Med J. 2006;96(4):320-322.

\section{Tables}


Table 1: Characteristics of articles included in review

\begin{tabular}{|c|c|c|c|c|c|c|}
\hline S/NO & $\begin{array}{l}\text { AUTHOR } \\
\text { (YEAR) }\end{array}$ & COUNTRY & $\begin{array}{l}\text { TARGET } \\
\text { GROUP } \\
\text { (SETTING) }\end{array}$ & $\begin{array}{l}\text { TYPE OF } \\
\text { STUDY/DESIGN }\end{array}$ & OUTCOMES & SUMMARY OF RELEVANT RESULTS \\
\hline 1 & $\begin{array}{l}\text { Dada et al. } \\
(2009)^{21}\end{array}$ & Nigeria & $\begin{array}{l}\text { Patients with } \\
\text { musculoskeletal } \\
\text { injury treated } \\
\text { strictly by a } \\
\text { TBS }\end{array}$ & $\begin{array}{l}\text { Prospective, } \\
\text { non- } \\
\text { interventional } \\
\text { study; } 121 \\
\text { patients with } \\
155 \\
\text { musculoskeletal } \\
\text { injuries }\end{array}$ & $\begin{array}{l}168 \\
\text { complications } \\
\text { of treatment } \\
\text { by TBS. } \\
\text { Cost of } \\
\text { treatment by } \\
\text { TBS } \\
\text { compared to } \\
\text { orthodox } \\
\text { surgery. }\end{array}$ & $\begin{array}{l}\text { 1. Mal-union and non-union which each } \\
\text { accounted for } 27 \text { (16.1\%) cases. } \\
\text { 2. The cost of treatment of the TBS } \\
\text { ranged from USD 18-380, whereas, at the } \\
\text { Orthopedic Hospital, it ranged from USD } \\
\text { 34-98. }\end{array}$ \\
\hline 2 & $\begin{array}{l}\text { Callistus et } \\
\text { al. (2013) }\end{array}$ & Ghana & $\begin{array}{l}\text { Patients with } \\
\text { musculo- } \\
\text { skeletal injuries } \\
\text { treated by TBS } \\
\text { with } \\
\text { complications } \\
\text { over } 5 \text { years in } \\
\text { Northern Ghana }\end{array}$ & $\begin{array}{l}\text { Prospective } \\
\text { non- } \\
\text { interventional } \\
\text { study of } 230 \\
\text { patients }\end{array}$ & $\begin{array}{l}\text { Complications } \\
\text { of TBS } \\
\text { Treatment. }\end{array}$ & $\begin{array}{l}\text { 1. Non-Union }(20.9 \%) \\
\text { 2. Malunion }(31.3 \%) \\
\text { 3. Infection }(17 \%) \\
\text { 4. Ankylosis }(7.8 \%) \\
\text { 5. Paralysis }(5.2 \%) \\
\text { 6. Gangrene }(2.6 \%) \\
\text { 7. Osteonecrosis }(5.7 \%)\end{array}$ \\
\hline 3 & $\begin{array}{l}\text { Panigrahi } \\
\text { et al. } \\
(2017)\end{array}$ & India & $\begin{array}{l}120 \text { patients } \\
\text { who presented } \\
\text { to the } \\
\text { outpatient } \\
\text { department of a } \\
\text { University } \\
\text { Teaching } \\
\text { Hospital over a } \\
\text { 2-year period } \\
\text { with fracture } \\
\text { complications } \\
\text { from TBS } \\
\text { treatment }\end{array}$ & $\begin{array}{l}\text { Prospective, } \\
\text { non-randomized } \\
\text { study of } 120 \\
\text { patients with } \\
\text { fracture } \\
\text { complications }\end{array}$ & $\begin{array}{l}\text { Pattern of } \\
\text { complications } \\
\text { of traditional } \\
\text { bonesetters' } \\
\text { treatment. }\end{array}$ & $\begin{array}{l}\text { 1. Malunion (46\%) } \\
\text { 2. Non-union }(20 \%) \\
\text { 3. Chronic osteomyelitis (6\%) } \\
\text { 4. Limb ischemia }(28 \%)\end{array}$ \\
\hline 4 & $\begin{array}{l}\text { Onuminya } \\
\text { et al. } \\
(1999)^{4}\end{array}$ & Nigeria & $\begin{array}{l}\text { Patients in } \\
\text { Northern } \\
\text { Nigeria who } \\
\text { suffered } \\
\text { complications } \\
\text { of limb } \\
\text { fractures and } \\
\text { managed by } \\
\text { TBS }\end{array}$ & $\begin{array}{l}\text { Retrospective } \\
\text { study; } 25 \\
\text { patients aged } \\
\text { between } 5-50 \\
\text { years }\end{array}$ & $\begin{array}{l}\text { Complications } \\
\text { of treatment } \\
\text { by TBS }\end{array}$ & $\begin{array}{l}\text { 1. Gangrene (60\%) } \\
\text { 2. Cellulitis (20\%) } \\
\text { 3. Compartment syndrome (20\%) }\end{array}$ \\
\hline 5 & $\begin{array}{l}\text { Nwankwo } \\
\text { et al. } \\
(2005)^{24}\end{array}$ & Nigeria & $\begin{array}{l}15 \text { patients } \\
\text { presenting with } \\
\text { limb gangrene; } \\
\text { aged 1-83 } \\
\text { years, who had } \\
\text { presented to a } \\
\text { TBS for } \\
\text { treatment of } \\
\text { musculoskeletal } \\
\text { injuries }\end{array}$ & $\begin{array}{l}\text { Prospective, } \\
\text { non-controlled } \\
\text { cohort study; } 15 \\
\text { patients }\end{array}$ & $\begin{array}{l}\text { Outcomes in } \\
\text { patients who } \\
\text { had been to a } \\
\text { TBS after } \\
\text { they had } \\
\text { reported to } \\
\text { hospital }\end{array}$ & $\begin{array}{ll}\text { 1. } & \text { Gangrene }(100 \%) \\
\text { 2. Toxemia }(93.3 \%) \\
\text { 3. Amputation }(100 \%) \\
\text { 4. Death }(26.6 \%)\end{array}$ \\
\hline 6 & $\begin{array}{l}\text { Zehir et al. } \\
(2015)^{30}\end{array}$ & Turkey & $\begin{array}{l}\text { Bonesetter- } \\
\text { intervened } \\
\text { patients with } \\
\text { complications } \\
\text { of fractures } \\
\text { treatment }\end{array}$ & $\begin{array}{l}\text { Retrospective } \\
\text { analysis of } \\
\text { hospital records }\end{array}$ & $\begin{array}{l}\text { Complications } \\
\text { of treatment } \\
\text { by a TBS in } \\
55 \text { patients } \\
\text { who } \\
\text { presented }\end{array}$ & $\begin{array}{ll}\text { 1. } & \text { Joint stiffness }(14.8 \%) \\
\text { 2. } & \text { Degenerative arthritis }(6.2 \%) \\
\text { 3. } & \text { Permanent nerve injury }(3.1 \%) \\
\text { 4. } & \text { Skin necrosis }(3.1 \%) \\
\text { 5. } & \text { Deformity }(2.5 \%) \\
\text { 6. } & \text { Compartment syndrome }(1.8 \%)\end{array}$ \\
\hline
\end{tabular}




\begin{tabular}{|c|c|c|c|c|c|c|}
\hline & & & & & $\begin{array}{l}\text { with } \\
\text { complications. }\end{array}$ & $\begin{array}{l}\text { 7. Amputation }(1.2 \%) \\
\text { 8. Nonunion }(0.6 \%) \\
\text { 9. Limb shortening } \\
(0.6 \%)\end{array}$ \\
\hline 7 & $\begin{array}{l}\text { Huang } \\
(1986)^{19}\end{array}$ & China & $\begin{array}{l}16 \text { young } \\
\text { adults, aged 16- } \\
43 \text { years with } \\
\text { neglected } \\
\text { femoral neck } \\
\text { fractures } \\
\text { treated by a } \\
\text { "Chinese bone } \\
\text { setter" }\end{array}$ & $\begin{array}{l}\text { Retrospective } \\
\text { study of } 16 \\
\text { cases of } \\
\text { neglected } \\
\text { femoral neck } \\
\text { fractures }\end{array}$ & $\begin{array}{l}\text { Outcomes of } \\
\text { treatment of } \\
\text { neglected } \\
\text { femoral neck } \\
\text { fractures } \\
\text { initially seen } \\
\text { by bone } \\
\text { setters }\end{array}$ & $\begin{array}{l}\text { 1. Leg } \\
\text { shortening } \\
\text { 2. Upward displacement of the distal } \\
\text { fragment } \\
\text { 3. Variable degree of absorption of the } \\
\text { femoral neck or head }\end{array}$ \\
\hline 8 & $\begin{array}{l}\text { Doumi et } \\
\text { al. }(2007) \\
2009\end{array}$ & Sudan & $\begin{array}{l}46 \text { patients who } \\
\text { underwent } \\
\text { upper limb } \\
\text { amputations at } \\
\text { a teaching } \\
\text { hospital over } 5 \\
\text { year period }\end{array}$ & $\begin{array}{l}\text { Retrospective } \\
\text { study of } 46 \\
\text { patients who } \\
\text { had upper limb } \\
\text { amputations. }\end{array}$ & $\begin{array}{l}11 \text { out of the } \\
21 \text { children } \\
\text { had gangrene } \\
\text { from TBS } \\
\text { splintage as } \\
\text { the cause of } \\
\text { upper limb } \\
\text { amputation. }\end{array}$ & $\begin{array}{l}\text { TBS Splintage for limb injuries was a } \\
\text { major cause of gangrene in children } \\
(40.7 \%)\end{array}$ \\
\hline 9 & $\begin{array}{l}\text { MIAEL } \\
\text { Hag et al. } \\
(2010)\end{array}$ & Sudan & $\begin{array}{l}36 \text { Patients with } \\
\text { fractures } \\
\text { treated by TBS } \\
\text { presenting with } \\
\text { complications } \\
\text { over } 6 \text { months } \\
\text { at a Teaching } \\
\text { Hospital in } \\
\text { Khartoum } \\
\text { Sudan. }\end{array}$ & $\begin{array}{l}\text { Retrospective } \\
\text { review of } \\
\text { hospital } \\
\text { records. }\end{array}$ & $\begin{array}{l}\text { Complications } \\
\text { of patients } \\
\text { treated for } \\
\text { fractures by } \\
\text { bonesetters }\end{array}$ & $\begin{array}{l}\text { 1. Malunion (25.7\%) } \\
\text { 2. Nonunion }(20 \%) \\
\text { 3. Compartment syndrome }(14.3 \%) \\
\text { 4. Joint stiffness }(11.4 \%) \\
\text { 5. Gangrene }(8.6 \%)\end{array}$ \\
\hline 10 & $\begin{array}{l}\text { Warman et } \\
\text { al. (2018) }\end{array}$ & Indonesia & $\begin{array}{l}86 \text { Patients with } \\
109 \text { limb } \\
\text { fractures } \\
\text { presenting with } \\
\text { complications } \\
\text { from TBS } \\
\text { treatment } \\
\text { within one year. }\end{array}$ & $\begin{array}{l}\text { A hospital-based } \\
\text { retrospective } \\
\text { analysis of } \\
\text { medical } \\
\text { records. }\end{array}$ & $\begin{array}{l}\text { Early and late } \\
\text { complications } \\
\text { of fracture } \\
\text { treatment by } \\
\text { TBS }\end{array}$ & $\begin{array}{l}\text { 1. Malunion (54.7\%) } \\
\text { 2. Joint stiffness }(9.4 \%) \\
\text { 3. Non-Union }(18.7 \%) \\
\text { 4. Neurologic impairment }(7.8 \%)\end{array}$ \\
\hline 11 & $\begin{array}{l}\text { Zulfiqar et } \\
\text { al. (2018) }\end{array}$ & Pakistan & $\begin{array}{l}77 \text { Patients who } \\
\text { presented to } \\
\text { the outpatient } \\
\text { clinic after } \\
\text { being managed } \\
\text { by TBS over } 6 \\
\text { months period. }\end{array}$ & $\begin{array}{l}\text { Cross-sectional, } \\
\text { prospective, } \\
\text { non-randomized } \\
\text { study. }\end{array}$ & $\begin{array}{l}\text { Pattern of } \\
\text { complications } \\
\text { among } \\
\text { trauma } \\
\text { patients } \\
\text { treated by } \\
\text { TBS }\end{array}$ & $\begin{array}{l}\text { 1. Joint stiffness }(22 \%) \\
\text { 2. Volkmann's contracture }(20.8 \%) \\
\text { 3. Skin necrosis }(18.2 \%) \\
\text { 4. Non-union }(3.9 \%)\end{array}$ \\
\hline 12 & $\begin{array}{l}\text { Dastgir et } \\
\text { al. (2012) }\end{array}$ & Pakistan & $\begin{array}{l}86 \text { Patients with } \\
\text { musculoskeletal } \\
\text { injuries treated } \\
\text { by TBS before } \\
\text { presenting to a } \\
\text { teaching } \\
\text { hospital. } \\
\end{array}$ & $\begin{array}{l}\text { Prospective, } \\
\text { non-randomized } \\
\text { study. }\end{array}$ & $\begin{array}{l}\text { Presence of } \\
\text { complications } \\
\text { after } \\
\text { receiving TBS } \\
\text { treatment. }\end{array}$ & $\begin{array}{l}\text { 1. Non-union }(17.4 \%) \\
\text { 2. Malunion }(24.4 \%) \\
\text { 3. Chronic osteomyelitis }(17.4 \%) \\
\text { 4. Osteonecrosis }(10.4 \%) \\
\text { 5. Gangrene }(4.6 \%)\end{array}$ \\
\hline 13 & $\begin{array}{l}\text { Prasad et } \\
\text { al. (2015) }\end{array}$ & India & $\begin{array}{l}30 \text { orthopaedic } \\
\text { out-patients } \\
\text { with TBS } \\
\text { complications } \\
\text { over } 6 \text { months } \\
\text { period. }\end{array}$ & $\begin{array}{l}\text { Prospective } \\
\text { observational } \\
\text { study. }\end{array}$ & $\begin{array}{l}\text { Complications } \\
\text { resulting from } \\
\text { TBS } \\
\text { fractures } \\
\text { treatment }\end{array}$ & $\begin{array}{l}\text { 1. Malunion }(36.7 \%) \\
\text { 2. Non-union }(33.3 \%) \\
\text { 3. Myositis ossificans }(16.7 \%) \\
\text { 4. Infections }(6.7 \%)\end{array}$ \\
\hline 14 & $\begin{array}{l}\text { Kumma et } \\
\text { al. (2013) }\end{array}$ & Ethiopia & $\begin{array}{l}70 \text { patients } \\
\text { presenting to }\end{array}$ & $\begin{array}{l}\text { Prospective, } \\
\text { cross-sectional }\end{array}$ & $\begin{array}{l}\text { Frequency of } \\
\text { complications }\end{array}$ & $\begin{array}{l}\text { Joint stiffness (52.8\%) } \\
\text { Infection }(8.6 \%)\end{array}$ \\
\hline
\end{tabular}




\begin{tabular}{|c|c|c|c|c|c|c|}
\hline & & & $\begin{array}{l}\text { the emergency } \\
\text { unit of a } \\
\text { hospital with } \\
\text { history of } \\
\text { fracture } \\
\text { treatment by } \\
\text { TBS. }\end{array}$ & survey. & $\begin{array}{l}\text { arising from } \\
\text { the TBS } \\
\text { fracture } \\
\text { treatment }\end{array}$ & $\begin{array}{l}\text { Non-union }(5.7 \%) \\
\text { Gangrene }(4.3 \%) \\
\text { Volkmann's Contracture }(5.7 \%)\end{array}$ \\
\hline 15 & $\begin{array}{l}\text { Chowdhury } \\
\text { et al. } \\
\text { (2011) }\end{array}$ & Bangladesh & $\begin{array}{l}120 \text { Patients } \\
\text { with fractures } \\
\text { previously } \\
\text { treated by TBS } \\
\text { before } \\
\text { presenting to } 2 \\
\text { hospitals over a } \\
1 \text { year period. }\end{array}$ & $\begin{array}{l}\text { Prospective } \\
\text { multi-center } \\
\text { study. }\end{array}$ & $\begin{array}{l}\text { Methods of } \\
\text { treatment by } \\
\text { TBS that } \\
\text { resulted in } \\
\text { complications }\end{array}$ & $\begin{array}{l}\text { Malunion }(83.9 \%) \\
\text { Non-union }(14.7 \%) \\
\text { Joint stiffness }(11 \%) \\
\text { Infections }(22.1 \%) \\
\text { Gangrene } 1.5 \%\end{array}$ \\
\hline
\end{tabular}

Table 2 NHLBI Quality Assessment Tool for Observational Cohort and Cross-Sectional Studies 


\begin{tabular}{|c|c|c|c|c|c|c|c|c|c|}
\hline$/$ no & CRITERIA & $\begin{array}{l}\text { Dada } \\
\text { et al }\end{array}$ & $\begin{array}{l}\text { Callistus } \\
\text { et al }\end{array}$ & $\begin{array}{l}\text { Panigrahi } \\
\text { et al }\end{array}$ & $\begin{array}{l}\text { Onuminya } \\
\text { et al }\end{array}$ & $\begin{array}{l}\text { Nwankwo } \\
\text { et al }\end{array}$ & $\begin{array}{l}\text { Zehir } \\
\text { et al }\end{array}$ & Huang & $\begin{array}{l}\text { Doumi } \\
\text { et al }\end{array}$ \\
\hline & $\begin{array}{l}\text { Was the research question or objective in } \\
\text { this paper clearly stated? }\end{array}$ & YES & YES & YES & YES & YES & YES & YES & YES \\
\hline & $\begin{array}{l}\text { Was the study population clearly specified } \\
\text { and defined? }\end{array}$ & YES & YES & YES & YES & YES & YES & YES & YES \\
\hline & $\begin{array}{l}\text { Was the participation rate of eligible persons } \\
\text { at least } 50 \% \text { ? }\end{array}$ & CD & $\mathrm{CD}$ & NR & NR & NR & NR & NR & NR \\
\hline & $\begin{array}{l}\text { Were all the subjects selected or recruited } \\
\text { from the same or similar populations } \\
\text { (including the same time period)? Were } \\
\text { inclusion and exclusion criteria for being in } \\
\text { the study prespecified and applied uniformly } \\
\text { to all participants? }\end{array}$ & YES & NR & YES & NR & YES & YES & YES & NR \\
\hline & $\begin{array}{l}\text { Was a sample size justification, power } \\
\text { description, or variance and effect estimates } \\
\text { provided? }\end{array}$ & $\mathrm{NO}$ & $\mathrm{NO}$ & NO & $\mathrm{NO}$ & NO & $\mathrm{NO}$ & $\mathrm{NO}$ & $\mathrm{NO}$ \\
\hline & $\begin{array}{l}\text { For the analyses in this paper, were the } \\
\text { exposure(s) of interest measured prior to the } \\
\text { outcome(s) being measured? }\end{array}$ & YES & YES & YES & YES & YES & YES & YES & YES \\
\hline & $\begin{array}{l}\text { Was the timeframe sufficient so that one } \\
\text { could reasonably expect to see an } \\
\text { association between exposure and outcome if } \\
\text { it existed? }\end{array}$ & YES & YES & YES & YES & YES & YES & YES & YES \\
\hline & $\begin{array}{l}\text { For exposures that can vary in amount or } \\
\text { level, did the study examine different levels } \\
\text { of the exposure as related to the outcome } \\
\text { (e.g., categories of exposure, or exposure } \\
\text { measured as continuous variable)? }\end{array}$ & $\mathrm{NO}$ & $\mathrm{NO}$ & NR & YES & YES & $\mathrm{NO}$ & $\mathrm{NO}$ & NR \\
\hline & $\begin{array}{l}\text { Were the exposure measures (independent } \\
\text { variables) clearly defined, valid, reliable, and } \\
\text { implemented consistently across all study } \\
\text { participants? }\end{array}$ & YES & YES & YES & YES & YES & YES & $\mathrm{NO}$ & YES \\
\hline$j$ & $\begin{array}{l}\text { Was the exposure(s) assessed more than } \\
\text { once over time? }\end{array}$ & $\mathrm{NO}$ & $\mathrm{NO}$ & $\mathrm{NO}$ & $\mathrm{NO}$ & $\mathrm{NO}$ & $\mathrm{NO}$ & $\mathrm{NO}$ & $\mathrm{NO}$ \\
\hline 1 & $\begin{array}{l}\text { Were the outcome measures (dependent } \\
\text { variables) clearly defined, valid, reliable, and } \\
\text { implemented consistently across all study } \\
\text { participants? }\end{array}$ & YES & $\mathrm{NO}$ & YES & YES & YES & YES & YES & YES \\
\hline 2 & $\begin{array}{l}\text { Were the outcome assessors blinded to the } \\
\text { exposure status of participants? }\end{array}$ & NA & NA & NA & NA & NA & NA & NA & NA \\
\hline 3 & $\begin{array}{l}\text { Was loss to follow-up after baseline } 20 \% \text { or } \\
\text { less? }\end{array}$ & NR & NR & NR & NR & NR & NR & NR & NR \\
\hline \multirow[t]{2}{*}{$\overline{4}$} & $\begin{array}{l}\text { Were key potential confounding variables } \\
\text { measured and adjusted statistically for their } \\
\text { impact on the relationship between } \\
\text { exposure(s) and outcome(s)? }\end{array}$ & $\mathrm{NO}$ & $\mathrm{NO}$ & NO & $\mathrm{NO}$ & NO & $\mathrm{NO}$ & $\mathrm{NO}$ & $\mathrm{NO}$ \\
\hline & Rating & FAIR & POOR & FAIR & FAIR & GOOD & FAIR & FAIR & $\begin{array}{l}\text { FAIR } \\
\end{array}$ \\
\hline
\end{tabular}

Table 2 (contd.): NHLBI Quality Assessment Tool for Observational Cohort and Cross-Sectional Studies 


\begin{tabular}{|c|c|c|c|c|c|c|c|c|}
\hline & CRITERIA & $\begin{array}{l}\text { MIAEL } \\
\text { Hag et } \\
\text { al }\end{array}$ & \begin{tabular}{|l|} 
Warman \\
et al
\end{tabular} & $\begin{array}{l}\text { Zulfiqar } \\
\text { et al }\end{array}$ & $\begin{array}{l}\text { Dastgir } \\
\text { et al }\end{array}$ & $\begin{array}{l}\text { Prasad } \\
\text { et al }\end{array}$ & $\begin{array}{l}\text { Kumma } \\
\text { et al }\end{array}$ & $\begin{array}{l}\text { Chowdhury } \\
\text { et al }\end{array}$ \\
\hline & $\begin{array}{l}\text { Was the research question or objective in this paper } \\
\text { clearly stated? }\end{array}$ & YES & YES & YES & YES & YES & YES & YES \\
\hline & Was the study population clearly specified and defined? & YES & YES & YES & YES & NR & YES & YES \\
\hline & $\begin{array}{l}\text { Was the participation rate of eligible persons at least } \\
50 \% \text { ? }\end{array}$ & NA & NR & NR & NR & NR & NO & NR \\
\hline & $\begin{array}{l}\text { Were all the subjects selected or recruited from the } \\
\text { same or similar populations (including the same time } \\
\text { period)? Were inclusion and exclusion criteria for being } \\
\text { in the study prespecified and applied uniformly to all } \\
\text { participants? }\end{array}$ & YES & YES & YES & YES & YES & YES & YES \\
\hline & $\begin{array}{l}\text { Was a sample size justification, power description, or } \\
\text { variance and effect estimates provided? }\end{array}$ & NO & NO & NO & NO & NO & NO & NO \\
\hline & $\begin{array}{l}\text { For the analyses in this paper, were the exposure(s) of } \\
\text { interest measured prior to the outcome(s) being } \\
\text { measured? }\end{array}$ & YES & YES & YES & YES & NO & YES & YES \\
\hline & $\begin{array}{l}\text { Was the timeframe sufficient so that one could } \\
\text { reasonably expect to see an association between } \\
\text { exposure and outcome if it existed? }\end{array}$ & YES & YES & NO & YES & NO & $\mathrm{NO}$ & YES \\
\hline & $\begin{array}{l}\text { For exposures that can vary in amount or level, did the } \\
\text { study examine different levels of the exposure as } \\
\text { related to the outcome (e.g., categories of exposure, or } \\
\text { exposure measured as continuous variable)? }\end{array}$ & YES & YES & $\mathrm{NO}$ & $\mathrm{NO}$ & $\mathrm{NO}$ & YES & YES \\
\hline & $\begin{array}{l}\text { Were the exposure measures (independent variables) } \\
\text { clearly defined, valid, reliable, and implemented } \\
\text { consistently across all study participants? }\end{array}$ & YES & YES & YES & YES & YES & YES & YES \\
\hline 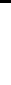 & $\begin{array}{l}\text { Was the exposure(s) assessed more than once over } \\
\text { time? }\end{array}$ & NO & $\mathrm{NO}$ & NO & $\mathrm{NO}$ & $\mathrm{NO}$ & $\mathrm{NO}$ & $\mathrm{NO}$ \\
\hline 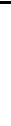 & $\begin{array}{l}\text { Were the outcome measures (dependent variables) } \\
\text { clearly defined, valid, reliable, and implemented } \\
\text { consistently across all study participants? }\end{array}$ & YES & YES & $\mathrm{NO}$ & YES & YES & YES & YES \\
\hline 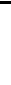 & $\begin{array}{l}\text { Were the outcome assessors blinded to the exposure } \\
\text { status of participants? }\end{array}$ & NA & NA & NA & NA & NA & NA & NA \\
\hline 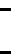 & Was loss to follow-up after baseline $20 \%$ or less? & NR & NR & NR & NR & NR & NR & NR \\
\hline . & $\begin{array}{l}\text { Were key potential confounding variables measured } \\
\text { and adjusted statistically for their impact on the } \\
\text { relationship between exposure(s) and outcome(s)? }\end{array}$ & NO & YES & NO & NO & NO & NA & YES \\
\hline & Rating & GOOD & GOOD & POOR & FAIR & POOR & FAIR & GOOD \\
\hline
\end{tabular}

\section{Figures}




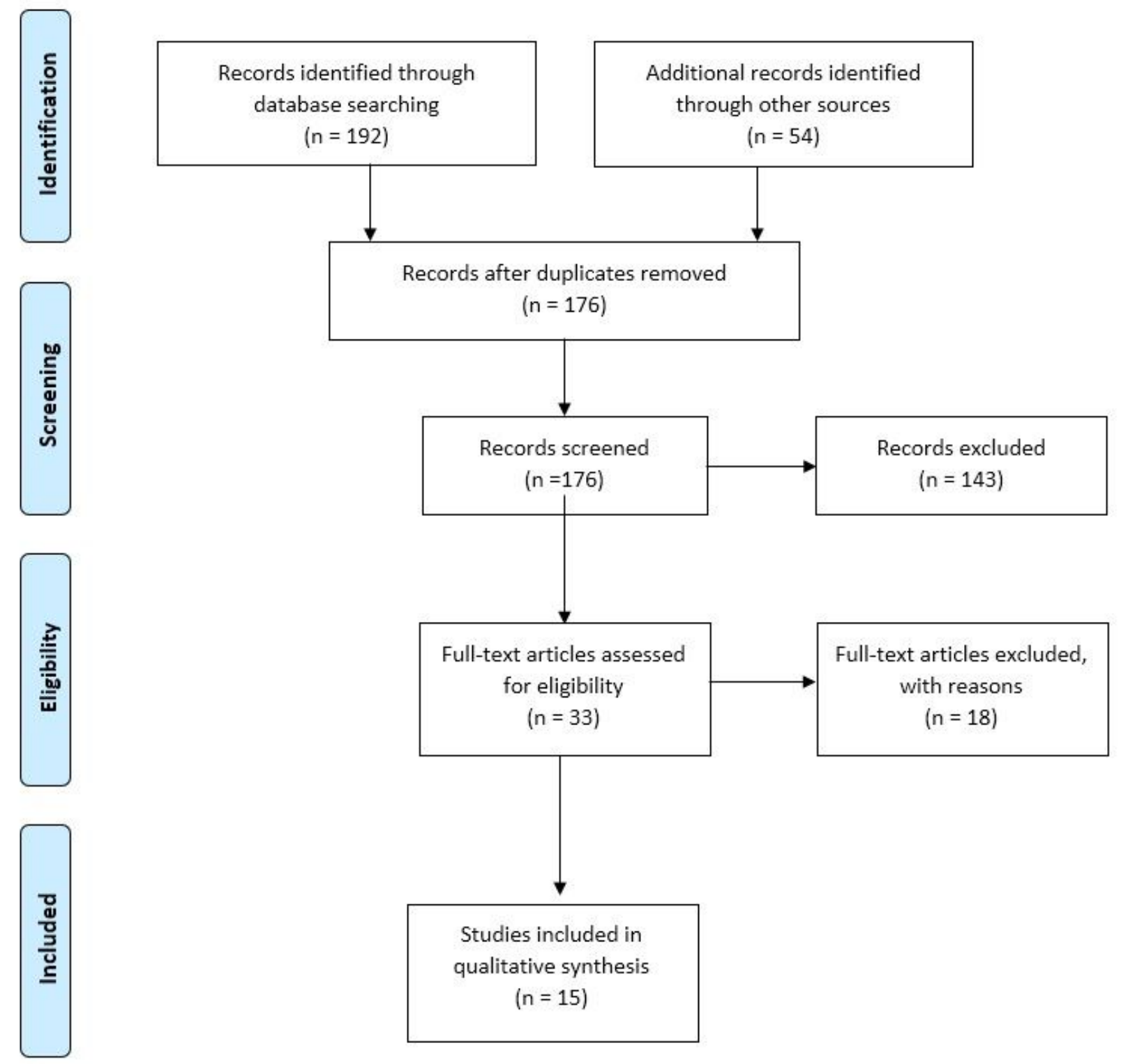

Figure 1

Flow chart of article selection process

\section{Supplementary Files}

This is a list of supplementary files associated with this preprint. Click to download.

- PRISMA2009checklistA.doc 